\title{
Why do Latin American firms hold so much more cash than they used to?*
}

\author{
Rodrigo Pérez Artica ${ }^{1}$ \\ iD https://orcid.org/0000-0002-7869-1994 \\ Email: rodrigo.perezartica@uns.edu.ar \\ Leandro Brufman² \\ Email: leandrobrufman@gmail.com
}

Nicolás Saguí1

Email: nicolas.sagui@uns.edu.ar

'Universidad Nacional del Sur, Instituto de Investigaciones Económicas y Sociales del Sur, Departamento de Economía, Buenos Aires, Argentina ${ }^{2}$ Independent researcher currently not affiliated, New York City, NY, United States of America

Received on 06.08.2017 - Desk acceptance on 07.09.2017 - $2^{\text {nd }}$ version approved on 12.14.2017 - Ahead of print on 07.30.2018

Associate Editor: Fernanda Finotti Cordeiro Perobelli

\begin{abstract}
This study assesses whether the trade-off or the pecking order theories explain the increased cash ratios in Latin American firms. It also assesses the explanatory power of additional variables that identify key macroeconomic features in Latin American economies. Due to its noticeable increase, cash became a key feature of Latin American firm performance over the last decades. The need for a better understanding is stressed by the fact that, during most of the last decade, these firms experienced a phase of accelerated economic growth and buoyant financial markets. The resulting surge in real investment opportunities within this period makes the growing cash holdings all the more puzzling. As far as we know, no other research addresses this issue in a direct way. There are robust facts about the increased cash holdings in Latin American firms. This article assesses traditional explanations and defines which fits more properly to the study sample. A complementary explanation regarding exchange rate exposure and key macroeconomic variables is constructed and empirically evaluated. To address potential sources of endogeneity, dynamic panel data methods are used. Particularly, the system generalized method of moments (GMM) was applied, as proposed by Blundell and Bond (1998). This article reports an increasing trend for corporate cash holdings in a sample of selected Latin American firms between 2000 and 2014. Likewise, net leverage and short-term debt show a declining trend over the same period. The trade-off theory may explain this. A substantial effect of macroeconomic variables particularly affecting firms that operate in the region is observed, such as exchange rate risks.
\end{abstract}

Keywords: corporate finance, cash holdings, capital structure, trade-off theory, Latin American firms.

Correspondence address

Rodrigo Pérez Artica

Instituto de Investigaciones Económicas y Sociales del Sur, Departamento de Economía

San Andrés, 800 - B8001

Bahía Blanca - Buenos Aires - Argentina

* Paper presented at the LI Annual Meeting of the Argentine Association of Political Economy, Tucumán, Argentina, November 2016. 


\section{INTRODUCTION}

This article reports an increasing trend for corporate cash holdings in a sample of selected Latin American firms since 2000, which occurred at a steady pace over the decade and spread similarly across various countries, firm-size segments, and industries. This trend also played a role in a fairly noticeable shift in the region's corporate balance sheet structure - at least for the large, listed firms.

The need for a better understanding of such increased corporate cash holdings is stressed by the fact that, during most of the last decade, the region went through a phase of accelerated economic growth and buoyant financial markets, within the upward phase of commodity export prices and the foreign capital inflow cycle. The resulting surge in real investment opportunities along that period makes the growing cash holdings all the more puzzling. However, as far as we know, there is no academic study addressing this issue.

The growing amount of cash held by Latin American firms reflects a similar performance of corporations in developed economies over the last 30 years. Moreover, it reproduces the foreign reserve accumulation by central banks in most developing economies over the past decade. Although substantial media and academic attention has been devoted both to growing cash holdings in developed countries (Bates, Kahle, \& Stulz, 2009; Pinkowitz \& Williamson, 2001; Pinkowitz, Stulz, \& Williamson, 2016) and the foreign reserve accumulation by central banks (Mohanty \& Turner, 2006), the recent increase in cash holdings by Latin American firms has been mostly overlooked by scholars.

The main purpose of this article is assessing the evolution of cash holdings in Latin American firms, thus shedding light on its determinants. As we show below, several rationales may explain the increased cash holdings in firms from developed economies. Thus, the first specific goal is discussing the validity of two broad literature strands for explaining the cash holding trends observed in Latin America, namely: the trade-off theory and the pecking order theory.
In addition, it is worth considering that these factors have a secondary impact on cash in Latin America. Indeed, Latin American firms face riskier macroeconomic environments that can exceed the effects of idiosyncratic causes. Thus, the second specific purpose is discussing the significance of macroeconomic factors as explanatory variables. Particularly, this study evaluates the impact of exchange rate exposure, the balance of payments, and economic growth as motives for holding cash.

First, this article provides evidence of increased cash holdings in a sample of large, listed, non-financial firms operating in the region. Evidence shows that this pattern is pervasive and holds for firms from different countries and industries, but this is stronger in Brazilian and Chilean firms.

Then, it discusses whether the trade-off or the pecking order theory prevails regarding the increased cash holdings in Latin American firms.

So, there is a need for investigating whether a priori factors that affect firms from developing markets play a relevant role in explaining cash holdings in firms. These factors are exchange rate exposure and key macroeconomic variables, such as exchange rate fluctuations, balance of payment, and gross domestic product (GDP) growth. In effect, empirical results argue for the relevance of macroeconomic factors, when explaining the increase in cash holdings in Latin American firms.

This article is organized as follows: Section 2 introduces facts concerning the increased cash holdings in the study sample. It also delves into other balance sheet changes that took place over the last decade, such as the net deleveraging process, decreased short-term debt, and the pitfalls of corporate capital expenditures. Section 3 provides a literature review on cash holdings in firms from developed economies and formulates a hypothesis regarding the effects of exchange rate exposure on cash accumulation in developing countries. Section 4 deals with dataset construction and methodological issues. Section 5 presents and discusses econometric results. Finally, section 6 summarizes and discusses the study findings. 


\section{INCREASED CASH HOLDINGS IN LATIN AMERICAN FIRMS}

How did cash ratios evolve in Latin American firms over the last decade and a half? Figure 1 displays the quarterly evolution of the median cash-to-assets ratio within the period from IV-2000 to IV-2014 in a sample of listed firms from 5 large Latin American countries: Argentina, Brazil, Chile, Mexico, and Peru. A full-sample median value is also included.

It has been observed that cash ratios (defined as the ratio of cash and equivalents to total assets) increased steadily during most of the period in focus, growing threefold until 2011 for the sample as a whole (from 2.5\% to $7.3 \%$ of the total assets). From then on, cash holdings decreased slightly or remained constant until the end of this period. Brazilian and Chilean firms showed a larger increase, growing almost fourfold from 2002 to 2010 , i.e. $2.6 \%-9.5 \%$ and $1.2 \%-4.9 \%$, respectively. In the other countries, cash ratios showed a steady but slower rise until 2010. By the end of this period, Brazilian firms are those holding the highest cash ratios in the sample (around $9.0 \%$ of the total assets).

Figure 1 shows the median cash-to-assets ratio for firms from each of the 5 countries included in the study sample.

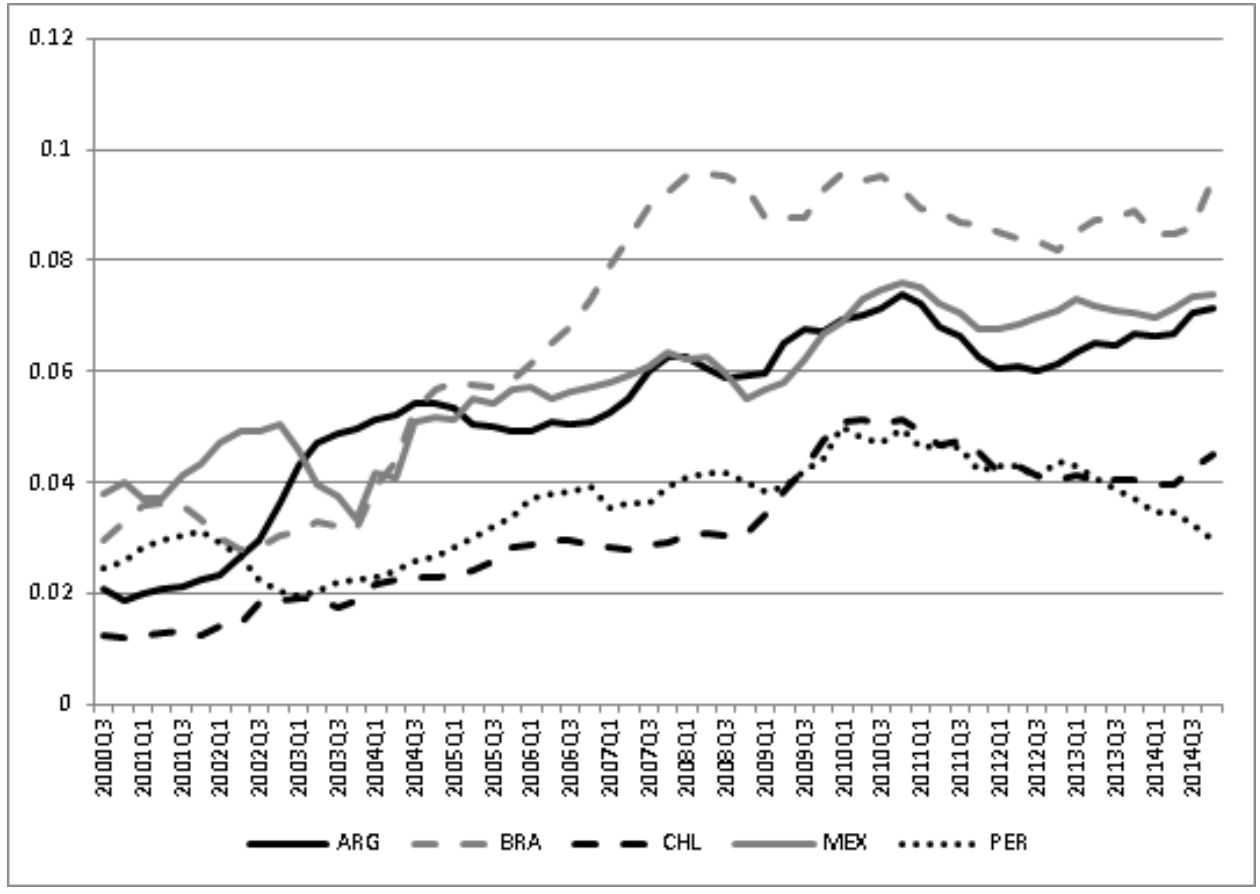

Figure 1 Median cash-to-assets ratio

$A R G=$ Argentina; $B R A=$ Brazil $; C H L=$ Chile; $M E X=$ Mexico; $P E R=$ Peru .

Source: Prepared by the authors.

Likewise, the balance sheet structure underwent analogous changes. According to Bates et al. (2009), the broad implications of cash ratios for the sample's financial structure are conveyed by computing the net leverage ratio. Leverage is measured as the ratio of total debt to total assets, while net leverage is measured as leverage minus the cash-to-assets ratio. Although no clear-cut trend emerges when considering the leverage ratios, net leverage shows a fairly declining trend over the period, mainly due to increased corporate cash holdings.

Figure 2 displays the quarterly evolution of the median net leverage ratio for firms from each of the 5 countries included in the study sample. Net leverage is measured as the ratio of total liabilities minus cash to total assets. 


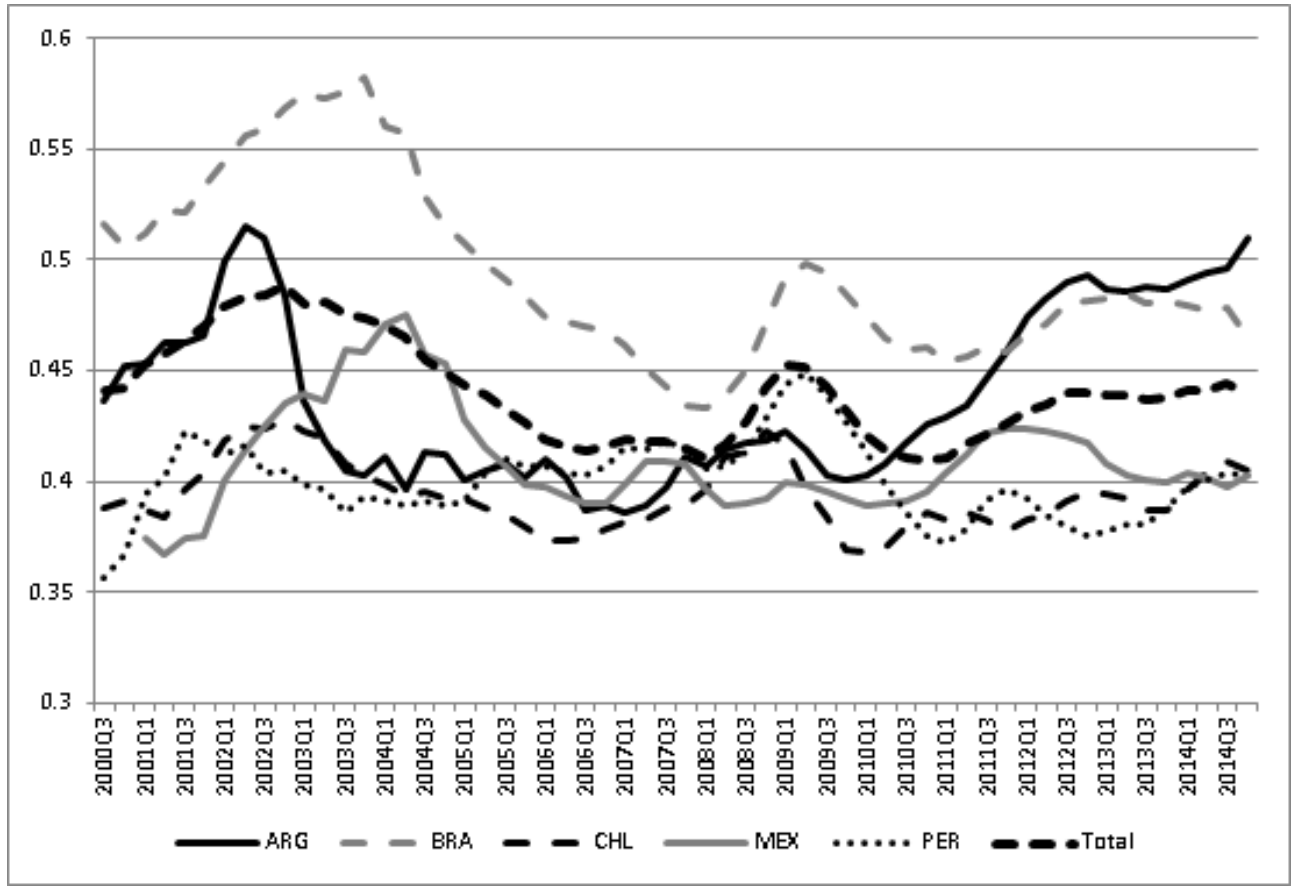

Figure 2 Median net leverage ratio

$A R G=$ Argentina; $B R A=$ Brazil $; C H L=$ Chile; $M E X=$ Mexico; $P E R=$ Peru.

Source: Prepared by the authors.

Also, this net deleveraging process goes along with a noticeable lower short-term debt ratio (ratio of current liabilities to total assets), at an average pace of $1.2 \%$ a year.

These findings on corporate debt dynamics may seem bewildering, as they occur during a global capital market bonanza, which should have driven private sector indebtedness upwards in the region. However, they are consistent with previous research claiming that, rather than increasing their leverage so as to boost private finance investment, Latin American firms took advantage of the favorable financial conditions by extending their average debt maturity (Didier \&
Schmukler, 2014) and improving their amortization profile (Bastos et al., 2015).

Moreover, increased cash holdings reflects a somewhat poor performance of corporate investment in the region over the last decade. In fact, Manuelito and Jiménez (2012) and the International Monetary Fund (2015) claims that in the light of several indicators (investment dynamism in other peripheral regions, improved demand and profitability, and higher private savings), private investment in Latin America fell behind expectations. Likewise, Pérez Artica, Delbianco and Brufman (2017) evidence a growing pattern of corporate net lending, mostly driven by corporate investment pitfalls.

\section{LITERATURE REVIEW ON CASH HOLDINGS IN DEVELOPED AND DEVELOPING}

\section{COUNTRIES}

\subsection{Literature on Corporate Cash Holdings in Developed Countries}

What are the causes driving the increased cash holdings in Latin American firms? In the light of the literature on corporate cash holdings in developed economies, this section outlines a preliminary set of factors driving the increased cash holdings observed in the study sample. The literature on this theme is classified according to whether research considers the possibility of attaining optimal cash levels or regards cash ratios as a residual outcome of a firm's financial function. This empirical study discusses whether one of these competing approaches prevails. 


\subsubsection{Trade-off theory and cash holdings.}

The trade-off theory claims that firms chose optimal cash holdings that maximize firm value. This approach may be split between two motives for demanding cash, i.e. the transaction motive and the precautionary motive.

\subsubsection{The transaction motive.}

Provided that external funding is assured for a given firm, it may also incur transaction costs when collecting cash, either through debt or equity issues, or even by turning non-cash assets into cash. Thus, firms adhere to a cash ratio that minimizes the sum of two cost types: on the one hand, the opportunity cost involved in holding non-profitable liquid assets; on the other, the transaction costs associated to each operation through which firms obtain cash. Classic studies on finance have modeled this motive (Baumol, 1952; Miller \& Orr, 1966).

Several factors determine the optimal cash level demanded due to the transaction motive.

First, the transaction costs of external funding are higher for firms that have never accessed public markets or credit lines through the banking system. Consequently, cash ratios should be lower for firms with higher, better, debt rating or credit lines. Also, liquidity may be assured by selling non-cash assets, but this can only be attained at a discount. Therefore, firms with mostly firm-specific operating assets are encouraged to hold higher liquid asset levels (Opler, Pinkowitz, Stulz, \& Williamson, 1999; Bates et al., 2009).

Second, according to Miller and Orr (1966), managing cash holdings may entail considerable economies of scale. As a result, larger firms are expected to have lower cash ratios. The recent literature focuses in the existence of economies of scale decreasing the need for cash when firm size increases. This was reported by Mulligan (1997) and Natke and Falls (2010).

\subsubsection{The precautionary motive.}

When access to external funding is affected, firms may hold cash in order to hedge against financial constraints preventing the completion of investment opportunities.

Many scholars have addressed the role played by liquidity holdings, cash flows, and capital structure management in moderating the effects of financial constraints on firm investment. Unable to obtain external funding, firms show cash-flow investment sensitivity, as a positive relationship of a firm's cash flow to its capital expenditures emerges (Ağca \& Mozumdar, 2017; Fazzari, Hubbard, \& Petersen, 1988; Stein, 2003).

Holmström and Tirole (2000) show that, faced with the risk of unforeseeable liquidity requirements, constrained firms demand a positive amount of cash. Significant studies reported a propensity of constrained firms to save cash out of cash flows, while the unconstrained firms' cash holdings show no systematical relation to cash flows (Acharya, Almeida, \& Campello, 2007; Almeida, Campello, \& Weisbach, 2004).

A variety of factors determines the level of precautionary cash demand in the presence of financial constraints.

First, Opler et al. (1999) show that corporate demand for cash decreases when access to credit and financial leverage improve. Larger firms and those with higher payout ratios are usually regarded as less financially constrained (for a discussion on these and other financial constraint measures, see Whited \& Wu, 2006).

Second, the cash ratio increases for constrained firms with better and more profitable investment opportunities (as measured by return on assets, cash flows, or marketto-book ratios), which act as proxies for financial distress costs (Bates et al., 2009).

Third, higher volatility of the operating environment and cash flow; many studies provide evidence that cash ratios are determined by cash flow and the volatility of other operating variables. In effect, idiosyncratic volatility impacted positively on cash ratios of U.S., German and French firms (Baum, Caglayan, \& Talavera, 2008; Baum, Schäfer, \& Talavera, 2007). Moreover, it has been shown that idiosyncratic volatility went through a protracted upward trend since the 1960s, mainly driven by the increased volatility of key variables, such as cash flow, net sales, and profitability (Irvine \& Pontiff, 2009). Crucially, macroeconomic volatility has shown to affect firm demand for cash in developed countries (Baum, Caglayan, Ozkan, \& Talavera, 2006), as well as in developing countries like Argentina, Mexico, and Turkey (Demir, 2009). 


\subsubsection{The pecking order theory.}

This subsection considers the assumption that firms do not pursue an optimal cash level, instead the latter fluctuates as a result of their financial inflows and payments. Myers (1984) outlines a financial hierarchy usually followed by firms in order to meet their liquidity needs, then moving from one source to the following when funding provided by the first is depleted: a) retained earnings; b) safe-debt issues; c) risky-debt issues; and d) stock issues.

The literature provides two alternative rationales for the financial hierarchy.

First, it may arise from an agency problem, with managers trying to avoid the financial discipline imposed on them by investors and creditors (Dittmar \& MahrtSmith, 2007; Jensen, 1986).

Second, it may be an optimal response to information asymmetries driving external funding costs upwards.

A classic model based on the latter rationale is provided by Myers and Majluf (1984). Information asymmetries may lead to substantial increase in the cost of equity, leading firms to avoid them. Consequently, if cash flows are high enough to invest in profitable opportunities and repay debt becoming due, firms accumulate the remaining cash flows as liquid assets. Hence, information issues shed light on the existence of a hierarchy and the idea of cash holdings as a byproduct of this financial behavior.

In this way, the cash ratio becomes a residual outcome of two opposite financial flows: on the one hand, the firm's cash flow and its applications; on the other, investment requirements and debt disbursements. Whenever the firm receives cash flows superseding the level of investment and debt payments, cash is stockpiled. If the opposite is true, cash ratios decrease as the firm's payments are met by using previously accumulated cash.

A logical consequence of this is that cash dividend payments decrease cash holdings. However, recent studies claim that payout ratios grow when the cash flow increases, exceeding the current and expected liquidity requirements (Benavides, Berggrun, \& Perafan, 2016). Therefore, in presence of substantially high cash flows, cash holdings and dividends may both increase at a time.

Summing up, if the pecking order theory explains the cash holdings evolution in Latin American firms, we expect a positive effect of cash flows and a negative effect of capital expenditures and debt repayments. Regarding dividend payments, they may relate positively or negatively to cash.

This article aims at assessing whether one of these broad assumptions prevails concerning the increased cash in Latin American firms. Comparing the trade-off and the pecking order theories on an empirical basis focuses both on their opposite predictions and on three variables: a) capital expenditures; b) firm size; and c) dividend payout ratio.

The trade-off theory assumes that: a) firms with higher capital expenditures should accumulate more cash to prevent financial constraints; b) larger firms should exhibit lower cash ratios, due to economies of scale and more pledgeable assets at hand; and c) firms paying dividends are less financially constrained and should hold less cash.

In contrast, according to the pecking order theory: a) firms with more capital expenditures should accumulate less cash; b) larger firms presumably have been more successful, hence they should have more cash after controlling for investment (Opler et al., 1999); and c) firms paying dividends may demand either less cash holdings or more cash holdings in the presence of high cash flows.

\subsubsection{Preliminary evidence in Latin American firms.}

A first hint on the actual impact of some determinants of cash holdings in the study sample may be grasped by tracking the evolution of firm's cash ratios in various segments or groups. Thus, this study assesses whether firm size plays a relevant role in shaping the average increase in the cash ratio by dividing the firms into size quintiles on the basis of the assets' book value averaged over the sample period.

Figure 3 shows the median cash ratio for the firm size quintiles over this period. In the light of the optimal cash ratio assumptions discussed above, Figure 3 depicts a rather counterintuitive pattern, where the higher size quintile for cash ratio shows a considerably sharper increase until the end of 2009. This counters the notion of economies of scale and the role played by pledgeable assets as a covenant making credit access easier for financially constrained firms. Instead, the size distribution of the cash ratio increase seems consistent with the pecking order theory. 


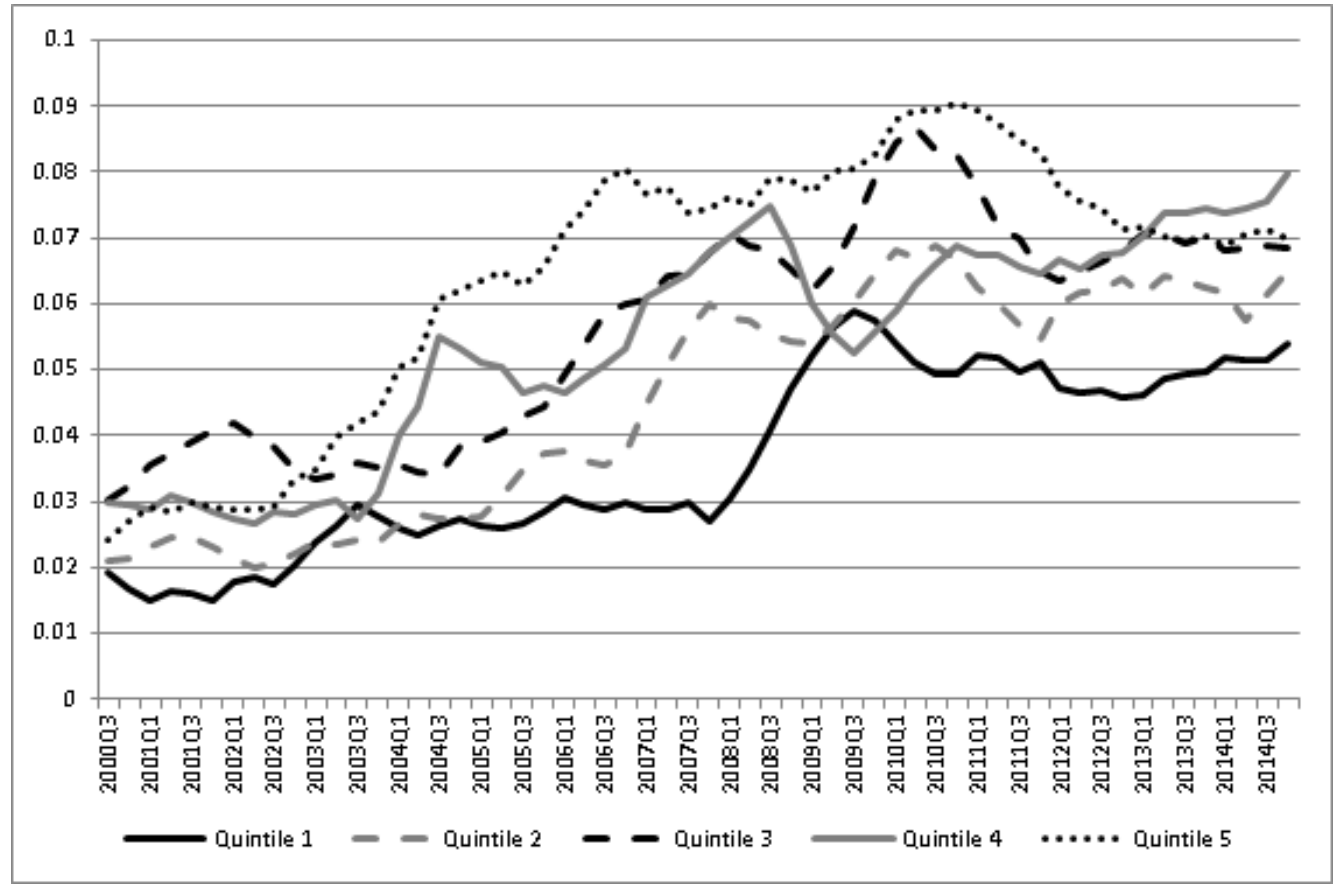

Figure 3 Evolution of the median cash-to-assets ratio for each firm-size quintile in the sample.

Source: Prepared by the authors.

Similarly, the effect of operating volatility may be roughly evaluated by considering the evolution of cash holdings in firms from various volatility quintiles. As a measure of operating volatility, the coefficient of variation of net cash flow from operating activities was computed for each firm. Figure 4 exhibits the median cash ratio for each operating volatility quintile. At first sight, similar to firm size, volatility seems to play a role opposite to what was expected, according to optimal cash ratio assumptions. The less volatile firms exhibit the larger increase and a clear-cut negative relationship of volatility to cash accumulation emerges. However, the econometric results shown in Section V, where this relationship is controlled for other determinants, suggest this raw-data approach may be misleading, as the coefficient for size becomes negative or non-significant and the coefficients for volatility become positive and statistically significant.

On the other hand, an important insight arises when we consider the role played by the net cash flow. Figure 4 illustrates how the cash ratio evolved for each sample quintile of net cash flow normalized by total assets. It points to a significantly larger upsurge in the cash ratio of firms in the quintiles receiving the higher net cash flows. Therefore, we can infer that firms with the most profitable investment opportunities are urged to stockpiling larger amounts of liquidity as an internal source of finance. In the same vein, this positive relation between net cash flows and cash ratios seems to confirm the pecking order theory. 


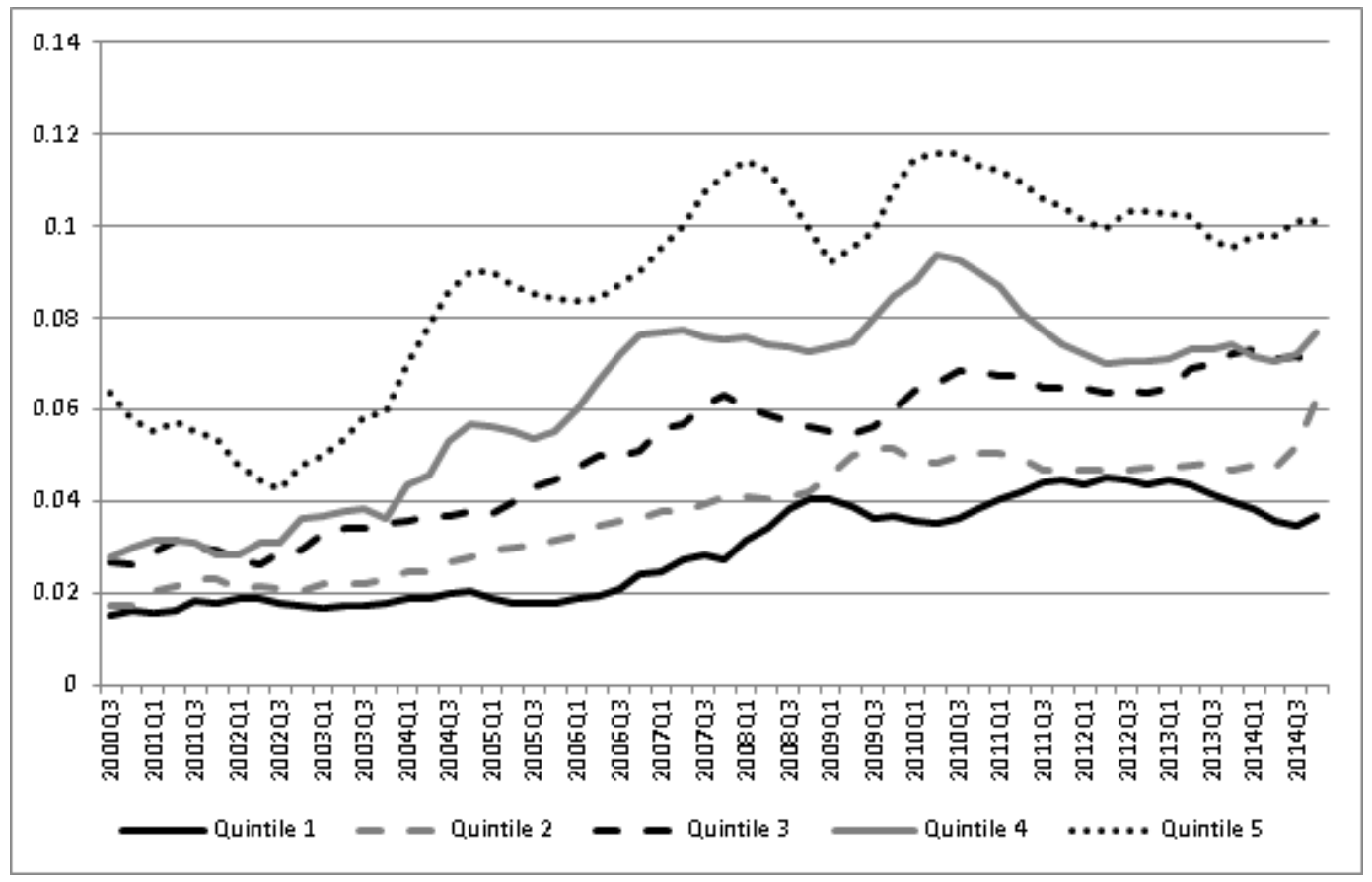

Figure 4 Median cash ratio for firms from each cash-flow quintile in the sample, as measured by the net cash flow ratio from operating activities to total assets.

Source: Prepared by the authors.

A preliminary insight on how access to external funding affects the demand for cash is provided by Figure 5 , which displays the median cash ratio for each leverage quintile. The highest increase in cash holdings occurred in the least indebted quintile, while firms in the fifth quintile drove a lower cash accumulation. This is consistent with the expected effect of leverage on transaction costs to access external funding and the need for more domestic funding experienced by less leveraged and more financially constrained firms.

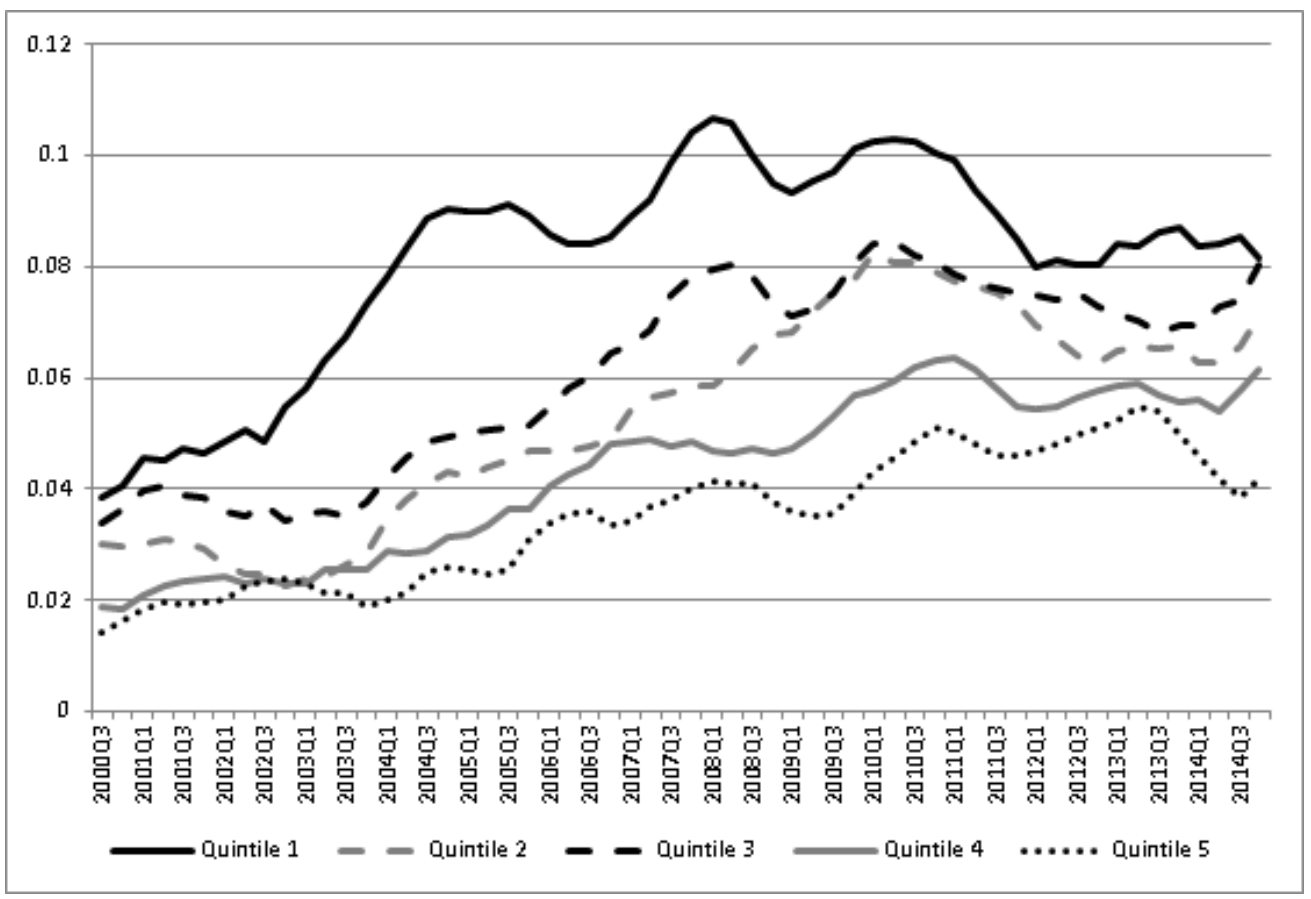

Figure 5 Median cash-to-assets ratio for firms in each leverage quintile. Leverage is measured as the ratio between total liabilities and total assets.

Source: Prepared by the authors. 


\subsection{Specific Determinants in Developing Markets: Foreign Exchange Exposure and Macroeconomic Variables}

Corporate cash holdings of Latin American firms have been barely dealt with by the literature on corporate finance. When addressed, the issue is taken as a byproduct of financial constraints (Panigo, Elosegui, \& Blanco, 2007). However, when considering the determinants of cash holdings for firms operating in developing economies, exchange rate exposure and a priori key macroeconomic indicators may play a relevant role.

\subsubsection{Exchange rate exposure.}

When operating in developing economies, firms are compelled to use a local currency prone to depreciation, thus jeopardizing their financial health. Indeed, contrary to what is observed in developed economies (Guay \& Kothari, 2003), when depreciation occurs, firms from developing countries face negative effects (Galindo, Panizza, \& Schiantarelli, 2003; Rossi Júnior, 2011).

Assessing the determinants of currency risk management, Schiozer and Saito (2009) found that the main determinant of financial risk for firms from Latin America is the cost of financial distress associated to balance sheet currency mismatch, i.e. holding liabilities in foreign currency and assets in local currency. It is worth noticing that Chui, Kuruc and Turner (2016) report an increasing trend for this kind of currency mismatches in Latin American firms over the sample period. However, when firms are able to use operational hedges, their currency exposure decreases (Schiozer \& Saito, 2009). For instance, an exporting firm whose revenue is earned in foreign currency faces less currency risk.

Scholars usually measure the exchange rate exposure as firm value sensitivity to foreign exchange variations (for a survey, see Muller \& Verschoor, 2006). However, in order to take into account the operational hedging mentioned above, a more direct approach was applied to the impact of exchange rate fluctuations on the firms' financial management and cash accumulation.

Two kinds of risks arising from exchange rate fluctuations were distinguished: a) the impact of exchange rate on the firms' operating cash flows; and b) the impact of exchange rate on the firms' balance sheet. The cash flow in local currency may increase or decrease due to currency depreciation. There are two typical cases.
First, following depreciation, exporting firms may experience an increased cash flow in local currency. Instead, firms from non-tradable sectors may see their costs increase faster than their revenue, thus facing a decrease in their cash flow.

Second, depreciation increases the burden of debt in foreign currency in the presence of currency mismatch, thus it may lead the firm to a costly financial distress. Financial disbursements, such as interest and principal repayment of debt in dollar, increase in local currency terms, while the value of assets may drop.

Currency risks may lead firms to increase cash holdings as a hedging strategy, when other hedging instruments are not available. Particularly, in foreign currency, cash holdings may eliminate or mitigate currency risk.

Summing up, two sources of exchange rate exposure may be identified and they may also be measured separately, so that their impact on cash holdings constitutes a research object. Namely, the operating exposure allows measuring the operating profit or cash flow sensibility to exchange rate; and the balance-sheet exposure accounts for the leverage sensibility to exchange rate.

\subsubsection{Macroeconomic variables.}

On the other hand, differences in the macroeconomic context may exert additional impacts on firm propensity to hold cash. Particularly, surplus balance of payments may lead firms to decrease cash holdings, as this reduces the need to hedge against exchange rate depreciation and involves expectation of domestic currency appreciation. Médici and Panigo (2015) show that, for countries facing balance of payments constraints, persistent net commercial surpluses, and capital inflows make credit access easier for financially constrained firms, thus promoting economic growth. This, in turn, can boost investment opportunities and affect the demand for cash. On the other hand, persistent balance of payments deficits stimulate exchange rate depreciation, thus leading firms to hedge against its damaging effects on performance.

Additionally, as discussed above (Baum et al., 2006), macroeconomic variables like GDP growth capture the aggregate fluctuations of investment opportunities. Additionally, the interest rate may be a proxy for the private cost of funds, thus affecting the opportunity cost to hold cash. 
In short, it is expected that exchange rate exposure, exchange rate depreciation, and balance of payments become non-negligible determinants of cash holdings in Latin American firms. Exchange rate and exchange rate exposure have positive effects, while balance of payments impacts negatively. Besides, as it represents aggregate investment opportunities, GDP growth is expected to produce higher cash holdings if the trade-off model prevails. Interest rates affect negatively the cash level, because they increase its opportunity cost.

\subsubsection{Development banking.}

Since the literature reports particularly strong causal effects of financial variables on cash holdings, it is worth noticing a main source of asymmetry in access to funding in Latin American countries: the presence of one of the largest development banks in the world, the Brazilian National Bank for Economic and Social Development (BNDES). Development banks are supposed to specialize in long-term lending, in fostering new industries and firms (Ferraz, Além, \& Madeira, 2013). Although there is ambiguous evidence of their effectiveness (Lazzarini, Musacchio, Bandeira-de-Mello, \& Marcon, 2014), it is worth controlling the study results with regard to this fact, as Brazilian firms may benefit from relatively easier and subsidized access to funding. Thus, financial constraints are expected to have weaker effects on firms from Brazil.

\section{DATA AND METHODOLOGY}

In order to investigate whether the theoretical determinants of cash holdings discussed above provide a suitable explanation for the cash holdings patterns observed in Latin American firms, an econometric analysis was performed. This section describes the database used and presents the baseline and extended models considered. Besides, the main variables are described and the main econometric issues are discussed.

The study sample is based on quarterly firm-level data, provided by the Compustat Global Fundamentals Database. As mentioned above, it covers 5 large Latin American countries, namely: Argentina, Brazil, Chile, Mexico, and Peru. The sample period is from 2000-Q1 to 2014-Q4. Financial and insurance companies are excluded (SIC Codes from 6000 to 6999).

Macroeconomic variables from the International Financial Statistics of the International Monetary Fund (IFS-IMF) are also included.

\subsection{The Model}

The dependent variable is defined as the cash-toassets ratio.

First, a baseline model was evaluated regressing the cash ratio on a set of independent variables, in order to capture the effects of the transaction and precautionary motives, as well as the pecking order theory. This allows evaluating whether the trade-off or the pecking order theory fits more properly to the sample. Subsequently, an extended model is discussed, adding two variables that reflect the impact of exchange rate exposure and a set of macroeconomic variables. The explanatory variables and the econometric issues are described in detail.

\subsubsection{Size.}

According to the literature (Bates et al., 2009), firm size is measured as the natural logarithm of the book value of total assets. The firm size coefficient is expected to be negative if firms pursue an optimal cash level. Instead, this study expects the size coefficient to be positive if the pecking order theory holds true.

\subsubsection{Net cash flow.}

This is represented by the cash flow from operating activities divided by the book value of total assets. According to both theories, this coefficient is expected to be positive.

\subsubsection{Dividends to assets.}

This measure is constructed as the ratio of cash dividends paid to total assets. The coefficient is expected to be negative if the precautionary motive holds, since firms with higher payouts may reduce the distribution of dividends when investment opportunities emerge and external funding is not available (Fazzari et al., 1988). Likewise, as discussed above, the pecking order theory does not predict a particular sign of the coefficient. 


\subsubsection{Gross capital expenditures.}

Capital formation is measured as the capital expenditures divided by the book value of total assets. According to the trade-off theory, we expect the coefficient on capital expenditures to be positive, given that more investment opportunities lead firms to accumulate more cash, as a hedging strategy against financial constraints. The pecking order theory predicts a negative coefficient.

\subsubsection{Sales growth.}

Another measure of investment and corporate growth opportunities is provided by the sales growth rate. This is computed as the first difference of net sales, divided by the net sales level. If higher investment opportunities increase the demand for cash, this coefficient is positive.

\subsubsection{Net working capital.}

Net working capital amounts to current assets like inventories and short-term receivable accounts. These are supposed to serve as substitutes for cash, hence a negative coefficient is expected (Bates et al., 2009; Opler et al., 1999).

\subsubsection{Leverage.}

As explained above, leverage is measured as the relation of the book value of total liabilities to total assets. Since this is a measure of the extent to which firms access credit and debt markets, this coefficient is expected to be negative, reflecting a lower need to hedge against financial constraints.

\subsubsection{Short-term leverage.}

A specific variable for the short term leverage was included, to differentiate the effects of overall indebtedness and debt coming due in the short term. This should generate cash requirements in the short term, thus increasing cash ratios. This is computed as the relation of current liabilities to total assets.

\subsubsection{Non-operating assets.}

As discussed above, firm-specific assets are expected to correlate positively with cash holdings, since diversified firms may rely on selling non-core assets at a lower discount, in order to assure liquidity. This idea is captured by measuring the proportion of total assets represented by assets other than the operating ones. Non-operating assets are defined as non-current assets other than the fixed assets. This is normalized through the book value of total assets and its coefficient is expected to be negative.

\subsubsection{Sales volatility.}

The operating environment volatility is measured by computing a 5-quarter rolling coefficient of variation of net sales. This coefficient is expected to be positive, since higher volatility increases hedging needs.

\subsubsection{Exchange rate operating exposure.}

This study measures the degree to which a firm is exposed to foreign exchange depreciation. As discussed above, two different channels are identified for this. First, through the impact of depreciation on the operating cash flow. Second, through the impact of depreciation on the balance sheet.

A firm's operating exposure to exchange rate is measured by computing the correlation between its cash flow from operations and the corresponding exchange rate in that country. Exchange rate is measured as a dollar price in local currency, so depreciation is captured through increased exchange rate. Equation 1 shows how this correlation is computed.

$$
\text { ER Operative Exposure } \text { Ex }_{i}=\operatorname{corr}\left(\text { ncf operations } \text { op }_{i t}, E R\right)
$$

For a given firm, a negative correlation between these variables is interpreted as showing a negative impact of depreciation on its operating performance. This should lead the firm to increase the demand for cash when it faces unpredicted liquidity requirements. Likewise, a positive correlation is interpreted as showing a positive impact of depreciation on its operating performance. This reduces the hedging need. Thus, the exchange rate operating exposure is expected to have a negative coefficient.

\subsubsection{Balance sheet exchange rate exposure.}

Likewise, the effect of foreign exchange depreciation on the balance sheet is obtained by computing a Pearson correlation coefficient between the country's foreign exchange and each firm's leverage ratio. 
Firms with a positive and high correlation coefficient are supposed to be negatively exposed to depreciation, thus facing a greater need for cash or other liquid assets as a hedging instrument. Firms with lower correlation coefficient, on the contrary, have balance sheets less vulnerable to exchange rate depreciation, so they need less cash. Consequently, the regression coefficient of the exchange rate balance sheet exposure is expected to be positive.

\subsubsection{Macroeconomic effects.}

This study aimed to capture the effects of macroeconomic forces mentioned above adding four macroeconomic variables to the study model:

1. Foreign exchange depreciation rate;

2. Balance of payment surplus (deficit) as a GDP percentage;

3. GDP growth rate; and

4. Active interest rate.
These four variables were obtained on a quarterly basis from the International Financial Statistics Database and the Balance of Payments Database - provided by the International Monetary Fund (IMF).

The stationarity of these macroeconomic variables is tested using the panel unit-root test proposed by Levin, Lin and Chu (2002). The results show that all four series are stationary about a deterministic trend.

Table 1 displays the $t$-statistics and the $p$ value according to the panel unit-root test, as proposed by Levin et al. (2002) for each of the macroeconomic variables included in the extended model of this study. The test specification includes panel means; a time deterministic trend and cross-sectional means were removed. The augmented Dickey-Fuller (ADF) regression lag structure is chosen by medians of the Akaike information criterion.

Table 1

Unit-root test for macroeconomic variables

\begin{tabular}{ccccc}
\hline & GDP & ER & BOP & Interest rate \\
\hline Non-adjusted $t$ & -6.6169 & -19.0543 & -14.4664 & -10.2793 \\
\hline Adjusted t* & -3.4801 & -18.6085 & -11.6946 & -5.9446 \\
\hline P value & 0.0003 & 0.0000 & 0.0000 & 0.0000 \\
\hline
\end{tabular}

Source: Prepared by the authors.

\subsubsection{Interaction terms for Brazilian firms.}

The ease of credit availability produced by development banks may relax the effect of credit constraints on Brazilian firms, which can access subsidized, longterm credit from the BNDES. Two interaction terms are included to capture this effect. First, relating a dummy for Brazilian firms to the logarithm of total assets. Given that financial constraints are negatively related to size and the Brazilian firms are supposed to face fewer constraints, the sign of this coefficient is expected to be positive. Second, an interaction term between a dummy for Brazilian firms and leverage is introduced. This coefficient is expected to have positive signs, showing that the negative relation of leverage to cash is weakened in the case of Brazilian firms.

\subsubsection{The econometric specification.}

In order to analyze the extent to which classical theories allows seeing the recent evolution of cash holdings in Latin American firms, this study estimates a baseline model defined by Equation 3 . 


$$
\begin{aligned}
\text { Cash Ratio }_{i t}= & \beta_{0}+\beta_{1} \text { Size }_{i t}+\beta_{2} \text { Net Cash Flow }_{i t}+\beta_{3} \text { Dividends }_{i t} \\
& +\beta_{4} \text { Capital Expenditures }_{i t}+\beta_{5} \text { Sales Growth }_{i t} \\
& +\beta_{6} \text { Net Working Capital } \\
& +\beta_{7} \text { Leverage }_{i t} \\
& +\beta_{8} \text { ShortTerm Debt } \\
& +\beta_{10} \text { Net Sales Volatility } \beta_{i t}+\beta_{11} \text { Cash Ration }_{i t-1}+u_{i}+e_{i t}
\end{aligned}
$$

where $u_{i}$ represents unobserved characteristics of firm $i$, and $e_{i t}$ is an independent and identically distributed error term for each firm $i$ and period $t$.

Some sources of endogeneity may affect the ordinary least squares (OLS) estimators. Barros and Silveira (2008) provide a review of simultaneous relations between some of the variables included in Equation 3. For instance, there may be a simultaneous relationship of financial leverage to investment opportunities, such as those captured by capital expenditures and sales growth. Additionally, the capital structure of a firm may influence its payout policy (Fama \& French, 2002).

To address these sources of endogeneity, the lag of the dependent variable is added as a regressor, something which makes the model dynamic in nature, and equations 3 and 4 estimate by using the system generalized method of moments (GMM), as proposed by
Blundell and Bond (1998). This method fits to dynamic models with unobserved heterogeneity and endogeneity. It combines the difference-GMM approach (which applies lagged independent variables as instruments at the equation level to address endogeneity) with the original equations at various levels. This procedure increases the efficiency of estimators when the series are very persistent. Therefore, their lagged levels are only weakly correlated with subsequent first differences (Blundell \& Bond, 1998). This study applies the approach proposed by Roodman (2009) to avoid biased estimators resulting from too many instruments. This consists of restricting the lag depth to two, at most, instead of using all available lags for instruments.

In a subsequent step, this equation was added with variables corresponding to exchange rate exposure and macroeconomic effects.

$$
\begin{aligned}
\text { Cash Ratio }_{i t}= & \beta_{0}+\beta_{1} \text { Size }_{i t}+\beta_{2} \text { Net Cash Flow }_{i t}+\beta_{3} \text { Dividends }_{i t} \\
& +\beta_{4} \text { Capital Expenditures }_{i t}+\beta_{5} \text { Sales Growth }_{i t} \\
& +\beta_{6} \text { Net Working Capital } \\
& +\beta_{7} \text { Leverage }_{i t} \\
& +\beta_{8} \text { ShortTerm Debt } \\
& +\beta_{10} \text { Net Sales Volatility }{ }_{i t}+\beta_{11} \text { Cash Ratio }_{i t-1} \\
& +\beta_{12} \text { ER Operative Exposure }+\beta_{13} \text { ER Balance Sheet Exposure }_{i t} \\
& +\beta_{14} \text { ER }+\beta_{15} \text { BOP }+\beta_{16} \text { GDP }+\beta_{17} \text { Interest Rate }+u_{i}+e_{i t}
\end{aligned}
$$

A Wald test was used for testing whether the new variables provide the estimates with accuracy. Finally, interaction terms are included to highlight the role played by the Brazilian public development bank credits. These new variables capture the effect that financial constraints and capital structure variables of Equation 3 have on cash ratios, particularly for Brazilian firms. 


\section{ECONOMETRIC RESULTS}

Table 1 displays the econometric results for equations 3 and 4 and for an additional model including interaction terms for Brazilian firms. All 3 models underwent the second-order serial correlation test. The null hypothesis that the error term is not serially correlated cannot be rejected. Most $p$ values for the Hansen test reach the conventional significance levels with an average value of 0.747 . The $p$ values for the difference-in-Hansen tests regarding the validity of instruments are also acceptable. The validity of the subsets of instruments is established for all regressions.

The $p$ values of both Wald tests shown at the bottom of columns B and C in Table 1 show that the variables included are jointly statistically significant and add valuable information to the regression. It is concluded that exchange rate exposure and macroeconomic variables, as well as the interaction terms for Brazilian firms, are relevant and worth including in the study model.

The firm size coefficients, the payout ratio, and the sales growth hold for all three models and they are consistent with the trade-off model. Larger firms and firms distributing more dividends hold lower cash levels, and firms with higher investment opportunities, as signaled by sales growth, demand more cash. The net cash flow also shows the expected positive sign.

Balance sheet variables, such as aggregate and shortterm leverage (except when interaction terms for Brazil are included), non-operating assets and net working capital also seem to confirm predictions of the trade-off theory. Firms with higher aggregate leverage seem to face less constraints when requesting foreign capital, thus they need less hedging. However, when more liabilities become due in the short term, firms hold more cash. Non-operating assets and net working capital seem to act as substitutes of cash.

Finally, the baseline model evaluation shows that more volatility in the operating environment as captured by the sales volatility leads firms to hold more cash.
Although capital expenditures reduce the amount of cash held by firms in the study sample, which tends to validate the pecking order theory, an overall interpretation of the results seems to favor the trade-off model.

Regarding the impact of exchange rate exposure, we find the expected effect of operating exposure. The negative coefficient means that firms whose cash flow fall when depreciation occurs tend to hedge against this risk by demanding more cash.

Balance sheet exposure, however, shows a statistically significant value, but opposite to the expected sign, i.e. firms with balance sheets more vulnerable to exchange rate depreciation tend to demand less cash. This may be signaling a propensity to hedge against this specific risk by using instruments other than cash (Schiozer \& Saito, 2009). This finding may also indicate that Latin American firms took advantage of the buoyant financial markets to extend the average maturity of their debt (Didier \& Schmukler, 2014), lowering the need for short term liquidity.

Regarding the impact of macroeconomic factors, as expected, we find that economic growth affected positively the demand for cash, which can involve higher investment opportunities and cash flows derived from higher economic activity. The exchange rate also had the expected result, with depreciation leading to higher cash holdings.

The remaining two macroeconomic indicators only show the expected signs when the interaction terms are included for Brazilian firms. In this last model, interest rates reduce the demand for cash, as expected, since they represent the opportunity cost. And the balance of payments also lowers cash, possibly reflecting less exchange rate hedging needs.

Finally, the positive signs of both interaction terms in Column C in Table 2 reveal that the financial constraints pushing firms to hold cash are less pervasive for Brazilian firms. 


\section{Table 2}

The determinants of cash holdings

\begin{tabular}{|c|c|c|c|}
\hline Independent variables & (A) & (B) & (C) \\
\hline \multirow[t]{2}{*}{ Log (total assets) } & $-0.00120^{* * *}$ & $-0.000787^{* * *}$ & \\
\hline & $(4.30 \mathrm{e}-05)$ & (6.75e-05) & $(0.000108)$ \\
\hline \multirow[t]{2}{*}{ Net cash flow to assets } & $0.151^{* * *}$ & $0.147^{* * *}$ & $0.148^{* * *}$ \\
\hline & $(0.000781)$ & $(0.00116)$ & $(0.00137)$ \\
\hline \multirow[t]{2}{*}{ Dividends to assets } & $-0.189 * * *$ & $-0.197 * * *$ & $-0.197 * * *$ \\
\hline & $(0.00116)$ & $(0.00158)$ & $(0.00203)$ \\
\hline \multirow[t]{2}{*}{ Gross capital formation } & $-0.196^{* * *}$ & $-0.196^{* * *}$ & $-0.191 * * *$ \\
\hline & $(0.00138)$ & $(0.00213)$ & $(0.00196)$ \\
\hline \multirow[t]{2}{*}{ Sales growth } & $0.0114^{* * *}$ & $0.0107^{* * *}$ & $0.0107^{* * *}$ \\
\hline & $(0.000262)$ & $(0.000273)$ & $(0.000257)$ \\
\hline \multirow[t]{2}{*}{ Net working capital } & $-0.0559^{* * *}$ & $-0.0547^{* * *}$ & $-0.0544^{* * *}$ \\
\hline & $(0.000748)$ & $(0.00108)$ & $(0.00140)$ \\
\hline \multirow[t]{2}{*}{ Leverage } & $0.0291^{* * *}$ & $0.0190^{* * *}$ & $-0.0147^{* * *}$ \\
\hline & $(0.000978)$ & $(0.00188)$ & $(0.00247)$ \\
\hline \multirow[t]{2}{*}{ Short term debt } & $0.0655^{* * *}$ & $0.0663^{* * *}$ & $0.0815^{* * *}$ \\
\hline & $(0.00200)$ & $(0.00281)$ & $(0.00266)$ \\
\hline \multirow[t]{2}{*}{ Non-operative assets } & $-0.0417^{* * *}$ & $-0.0426^{* * *}$ & $-0.0534^{* * *}$ \\
\hline & $(0.00121)$ & $(0.00131)$ & $(0.00152)$ \\
\hline \multirow[t]{2}{*}{ Moving coefficient of variation in net sales } & $0.00345^{* * *}$ & $0.00374 * * *$ & $0.00700^{* * *}$ \\
\hline & $(0.000223)$ & $(0.000274)$ & $(0.000526)$ \\
\hline \multirow[t]{2}{*}{ Operative exchange rate exposure } & & $-0.0191^{* * *}$ & $-0.0276^{* * *}$ \\
\hline & & $(0.00125)$ & $(0.00134)$ \\
\hline \multirow[t]{2}{*}{ Balance sheet exchange rate exposure } & & $-0.0106^{* * *}$ & $-0.0146^{* * *}$ \\
\hline & & $(0.000475)$ & $(0.000576)$ \\
\hline \multirow[t]{2}{*}{ Exchange rate depreciation } & & $0.0104^{* * *}$ & $0.0177^{* * *}$ \\
\hline & & $(0.000646)$ & $(0.000744)$ \\
\hline \multirow[t]{2}{*}{ Balance of payments } & & $0.00309 * * *$ & $-0.00344 * * *$ \\
\hline & & $(0.00108)$ & $(0.000898)$ \\
\hline \multirow[t]{2}{*}{ Economic growth } & & $0.0198^{* * *}$ & $0.0168^{* * *}$ \\
\hline & & $(0.000732)$ & $(0.00103)$ \\
\hline Active interest rate & & $0.000655^{* * *}$ & \\
\hline \multirow[t]{2}{*}{ L. (cash ratio) } & $0.807^{* * *}$ & $0.801^{* * *}$ & $0.782^{* * *}$ \\
\hline & $(0.00139)$ & $(0.00113)$ & $(0.00212)$ \\
\hline \multirow[t]{2}{*}{ Brazil*log (total assets) } & & & $0.00221^{* * *}$ \\
\hline & & & $(0.000273)$ \\
\hline \multirow[t]{2}{*}{ Brazil*leverage } & & & $0.0118^{* * *}$ \\
\hline & & & $(0.00384)$ \\
\hline \multirow[t]{2}{*}{ Constant } & $0.0290^{* * *}$ & $0.0268^{* * *}$ & $0.0396^{* * *}$ \\
\hline & $(0.000289)$ & $(0.000918)$ & $(0.00131)$ \\
\hline AR (1) p value & 0.0000 & 0.0000 & 0.0000 \\
\hline AR (2) p value & 0.621 & 0.631 & 0.64 \\
\hline Hansen test $p$ value & 0.652 & 0.722 & 0.826 \\
\hline Wald test chi2 & & 1919.99 & 1458.58 \\
\hline Wald test $p$ value & & 0.0000 & 0.0000 \\
\hline Observations & 10.258 & 9.973 & 9.973 \\
\hline Number of firms & 595 & 595 & 595 \\
\hline
\end{tabular}

Source: Prepared by the authors. 


\section{SUMMARY AND DISCUSSION}

This article reports an increasing trend for cash holdings in non-financial firms from Latin America, at least since 2000 . This increase proceeded steadily until 2010, when cash holdings stabilized at a significantly higher level, continued growing at a slower pace, or decreased slightly depending on the country. Increased cash holdings constitute an intriguing fact, as they occurred during an economic growth phase with booming international conditions concerning export prices and capital inflows to the region, presumably providing a broad array of investment opportunities.

There is strong evidence supporting the trade-off theory. This suggests that cash holdings were accumulated mainly for precautionary motives, in order to hedge against potential financial constraints.

Additionally, Latin American firms seem to experience additional motives for holding cash related to currency risks. Specifically, it was found that hedging against exchange rate risks affecting the operational cash flows is a statistically relevant motive. This study does not confirm that hedging against balance sheet currency mismatch plays the role expected for demanding cash.

The macroeconomic environment exerts relevant effects on the firms' demand for cash. It is worth stressing that, within the sample period, aggregate economic growth seems to increase the demand for cash, as well as exchange rate depreciation.

Finally, the ease of financial conditions due to development banking credit in Brazil, through the BNDES, also seems to weaken the financial constraints motive for demanding cash in Brazilian firms.

The positive impact of balance of payments surplus on the firms' cash holdings is a particularly puzzling fact, as the opposite effect is expected. However, a broader perspective shows that this behavior was also observed in the central banks of the region, mainly as a precautionary procedure against future drop-off in the foreign capital and commercial inflows. The specificities of this shared hedging strategy against a common macroeconomic risk still lack investigation, constituting a theme for further research.

\section{REFERENCES}

Acharya, V. V., Almeida, H., \& Campello, M. (2007). Is cash negative debt? A hedging perspective on corporate financial policies. Journal of Financial Intermediation, 16(4), 515-554. Retrieved from https://doi.org/10.1016/j.jfi.2007.04.001

Ağca, Ş., \& Mozumdar, A. (2017). Investment-cash flow sensitivity: fact or fiction? Journal of Financial and Quantitative Analysis, 52, 1111-1141. Retrieved from https:// doi.org/10.1017/S0022109017000230

Almeida, H., Campello, M., \& Weisbach, M. S. (2004). The cash flow sensitivity of cash. The Journal of Finance, 59(4), 1777-1804. Retrieved from https://doi.org/10.1111/j.15406261.2004.00679.x

Barros, L. A. B. D. C., \& Silveira, A. D. D. (2008). Excesso de confiança, otimismo gerencial e os determinantes da estrutura de capital. Revista Brasileira de Finanças, 6(3), 293-334.

Bastos, F. R., Kamil, H., Sutton, B., Meier, A., Werner, A., Srinivasan, K., ... Garcia-Escribano, M. (2015). Corporate financing trends and balance sheet risks in Latin America: taking stock of 'the bon(d)anza' (Working Paper). Washington, DC: International Monetary Fund.

Bates, T. W., Kahle, K., \& Stulz, R. M. (2009). Why do U.S. firms hold so much than they used to? Journal of Finance, 64(5), 1985-2021. Retrieved from http://onlinelibrary.wiley.com/ doi/10.1111/j.1540-6261.2009.01492.x/full

Baum, C. F., Caglayan, M., Ozkan, N., \& Talavera, O. (2006). The impact of macroeconomic uncertainty on non-financial firms demand for liquidity: a note. Review of Financial Economics, 15(4), 289-304. Retrieved from https://doi.org/10.1016/j. rfe.2010.06.004

Baum, C. F., Caglayan, M., \& Talavera, O. (2008). Uncertainty determinants of firm investment. Economics Letters, 98(3), 282-287. Retrieved from https://doi.org/10.1016/j. econlet.2007.05.004

Baum, C. F., Schäfer, D., \& Talavera, O. (2007, January). The effects of industry-level uncertainty on cash holdings: the case of Germany (Working Paper). [s.l]: [s.n].

Baumol, W. J. (1952). The transactions demand for cash: an inventory theoretic approach. The Quarterly Journal of Economics, 66(4), 545-556. Retrieved from https://doi. org/10.2307/1882104

Benavides, J., Berggrun, L., \& Perafan, H. (2016). Dividend payout policies: evidence from Latin America. Finance Research Letters, 17, 197-210. Retrieved from https://doi.org/10.1016/j. frl.2016.03.012

Blundell, R., \& Bond, S. (1998). Initial conditions and moment restrictions in dynamic panel data models. Journal of Econometrics, 87(1), 115-143. Retrieved from https://doi. org/10.1016/S0304-4076(98)00009-8

Chui, M., Kuruc, E., \& Turner, P. (2016). A new dimension to currency mismatches in the emerging markets: non-financial companies (Working Paper). [s.l]: [s.n].

Demir, F. (2009). Financial liberalization, private investment and portfolio choice: financialization of real sectors in emerging 
markets. Journal of Development Economics, 88(2), 314-324. Retrieved from https://doi.org/10.1016/j.jdeveco.2008.04.002

Didier, T., \& Schmukler, S. L. (2014). Debt markets in emerging economies: major trends. Comparative Economic Studies, 56(2), 200-228. Retrieved from https://doi.org/10.1057/ ces. 2014.4

Dittmar, A., \& Mahrt-Smith, J. (2007). Corporate governance and the value of cash holdings. Journal of Financial Economics, 83(3), 599-634. Retrieved from https://doi.org/10.1016/j. jifineco.2005.12.006

Fama, E., \& French, K. R. (2002). Testing trade-off and pecking order predictions about dividends and debt. The Review of Financial Studies, 15(1), 1-33.

Fazzari, S., Hubbard, G., \& Petersen, B. C. (1988). Financing constraints and corporate investment. Brookings Papers on Economic Activity, 1988(1), 141-195. Retrieved from https:// doi.org/10.1016/j.jfineco.2007.11.005

Ferraz, J. C., Além, A. C., \& Madeira, R. F. M. (2013). A contribuição dos bancos de desenvolvimento para o financiamento de longo prazo. Revista do BNDES, (40), 5-42.

Galindo, A., Panizza, U., \& Schiantarelli, F. (2003). Debt composition and balance sheet effects of currency depreciation: a summary of the micro evidence. Emerging Markets Review, 4(4), 330-339. Retrieved from https://doi. org/10.1016/S1566-0141(03)00059-1

Guay, W., \& Kothari, S. P. (2003). How much do firms hedge with derivatives? Journal of Financial Economics, 70(3), 423-461. Retrieved from https://doi.org/10.1016/S0304405X(03)00179-X

Holmström, B., \& Tirole, J. (2000). Liquidity and risk management. Journal of Money, Credit and Banking, 32(3), 295-319. Retrieved from https://doi.org/10.2307/2601167

International Monetary Fund. (2015). Economic outlook: Western hemisphere. Washington, DC: IMF.

Irvine, P. J., \& Pontiff, J. (2009). Idiosyncratic return volatility, cash flows, and product market competition. Review of Financial Studies, 22(3), 1149-1177. Retrieved from https:// doi.org/10.1093/rfs/hhn039

Jensen, M. C. (1986). Agency costs of free cash flow, corporate finance, and takeovers. The American Economic Review, 76(2), 323-329.

Lazzarini, S. G., Musacchio, A., Bandeira-de-Mello, R., \& Marcon, R. (2014). What do State-owned development banks do? Evidence from BNDES, 2002-09. World Development, $66,237-253$. Retrieved from https://doi.org/10.1016/j. worlddev.2014.08.016

Levin, A., Lin, C. F., \& Chu, C. S. J. (2002). Unit root tests in panel data: asymptotic and finite-sample properties. Journal of Econometrics, 108(1), 1-24. Retrieved from https://doi. org/10.1016/S0304-4076(01)00098-7

Manuelito, S., \& Jiménez, L. F. (2012). Stylized features of the investment-growth connection in Latin America, 1980-2012. Cepal Review, 115, 7-22.

Médici, F., \& Panigo, D. T. (2015). Balance-of-paymentconstrained growth in unbalanced productive structures: disregarded terms of trade negative effects. Journal of Post
Keynesian Economics, 38(2), 192-217. Retrieved from https:// doi.org/10.1080/01603477.2015.1065673

Miller, M. H., \& Orr, D. (1966). A model of the demand for money by firms. The Quarterly Journal of Economics, 80(3), 413-435.

Mohanty, M., \& Turner, P. (2006, September). Foreign exchange reserve accumulation in emerging markets: what are the domestic implications? BIS Quarterly Review, 39-52.

Muller, A., \& Verschoor, W. F. C. (2006). Asymmetric foreign exchange risk exposure: evidence from U.S. multinational firms. Journal of Empirical Finance, 13(4-5), 495-518. Retrieved from https://doi.org/10.1016/j.jempfin.2006.01.003

Mulligan, C. B. (1997). Scale economies, the value of time, and the demand for money: longitudinal evidence from firms. Journal of Political Economy, 105(5), 1061-1079. Retrieved from https://doi.org/10.2307/259249

Myers, S. C. (1984). The capital structure puzzle author. The Journal of Finance, 39(3), 575-592.

Myers, S. C., \& Majluf, N. S. (1984). Corporate financing and investment decisions when firms have information that investors do not have. Journal of Financial Economics, 13(2), 187-221. Retrieved from https://doi.org/10.1016/0304405X(84)90023-0

Natke, P. A., \& Falls, G. A. (2010). Economies of scale and the demand for money. Small Business Economics, 35(3), 283-298. Retrieved from https://doi.org/10.1007/s11187-008-9161-7

Opler, T., Pinkowitz, L., Stulz, R. M., \& Williamson, R. (1999). The determinants and implications of corporate cash holdings. Journal of Financial Economics, 52(1), 3-46. Retrieved from https://doi.org/10.1016/S0304-405X(99)00003-3

Panigo, D., Elosegui, P., \& Blanco, F. E. (2007, December). El impacto asimétrico de las restricciones de financiamiento en Argentina. Comparación por sector, tamaño y origen del capital (1995-2003). Ensayos Económicos, 48, 73-107.

Pérez Artica, R., Delbianco, F., \& Brufman, L. (2017). El ahorro y la inversión corporativos en América Latina. Una indagación a nivel firma. Cuadernos de Economía, 36(71), 571-600. Retrieved from https://doi.org/10.15446/cuad.econ. v36n71.54259.Este

Pinkowitz, L., Stulz, R. M., \& Williamson, R. (2016). Do U.S. firms hold more cash than foreign firms do? Review of Financial Studies, 29(2), 309-348. Retrieved from https://doi. org/10.1093/rfs/hhv064

Pinkowitz, L., \& Williamson, R. (2001). Bank power and cash holdings: evidence from Japan. Review of Financial Studies, 14(4), 1059-1082. Retrieved from https://doi.org/10.1093/ $\mathrm{rfs} / 14.4 .1059$

Roodman, D. (2009). A note on the theme of too many instruments. Oxford Bulletin of Economics and Statistics, 71(1), 135-158. Retrieved from https://doi.org/10.1111/j.14680084.2008.00542.x

Rossi Júnior, J. L. (2011). Exchange rate exposure, foreign currency debt, and the use of derivatives: evidence from Brazil. Emerging Markets Finance and Trade, 47(1), 67-89. Retrieved from https://doi.org/10.2753/REE1540-496X470104 
Schiozer, R. F., \& Saito, R. (2009). The determinants of currency risk management in Latin American nonfinancial firms. Emerging Markets Finance and Trade, 45(1), 49-71. Retrieved from https://doi.org/10.2753/REE1540-496X450104

Stein, J. C. (2003). Agency, information and corporate investment. In G. M. Constantinides, M. Harris, \& R. M. Stulz (Ed.),
Handbook of the economics of finance (vol. 1A, pp. 111-165). North Holland: Elsevier Science.

Whited, T. M., \& Wu, G. (2006). Financial constraints risk. Review of Financial Studies, 19(2), 531-559. Retrieved from https:// doi.org/10.1093/rfs/hhj012 